\title{
The Use \& Risk of endoscopy in the GI Tract Disease
}

\author{
Amar Deep ${ }^{1,2}$, Suchit Swaroop ${ }^{1}$ and Ajay Kumar ${ }^{2 *}$ \\ ${ }^{1}$ Eeperimental and Public Health Lab, Department of Zoology, University of Lucknow, India \\ ${ }^{2}$ Department of Medicine, King George's Medical University, India
}

Submission: March 21, 2017; Published: March 30, 2017

*Corresponding author: Ajay Kumar, Department of Medicine, King George’s Medical University, Lucknow, 226003, India, Tel: +91 9455519306;

Email: drajaymd12345@gmail.com; jsa.amardeep@gmail.com

\section{Editorial}

Endoscopy is a nonsurgical procedure used to examine a person's digestive tract. The primary aim of endoscopy in the management of patients with UGI symptoms is to detect organic disease. Using an endoscope, a flexible tube with a light and camera attached to it, your doctor can view pictures of your digestive tract on a color TV monitor. During an upper endoscopy, an endoscope is easily passed through the mouth and throat and into the esophagus, allowing the doctor to view the esophagus, stomach, and upper part of the small intestine.

Endoscopy is a team activity, requiring the collaborative talents of many people of different backgrounds and training. It is difficult to overstate the importance of an appropriate environment and professional support staff, in order to maintain patient comfort and safety, and to optimize clinical outcomes. Procedures are performed by many different types of doctor, including gastroenterologists, surgeons, and some radiologists. Specially trained endoscopy nurses are essential for endoscopic procedure. Because they have many important functions, including, prepare patients for their procedures, physically and mentally, set up all of the necessary equipment, assist the endoscopist during procedures, monitor patients' safety, sedation and recovery, clean, disinfect and process equipment, and also maintain quality control.

Typically, endoscopy is employed via an endoscope in a variety of medical procedures for both diagnostic and therapeutic purposes. An upper gastrointestinal (GI) endoscopy is where the doctor uses an instrument called an endoscope to look at the inside lining of your oesophagus (food pipe), stomach and duodenum (first part of the small intestine). This is done to look at reasons as to why you may have swallowing problems, nausea, vomiting, reflux, bleeding, indigestion, abdominal pain or chest pain [1]. Endoscopic procedure is done in the expert opinion for the disease such as dyspepsia, in the event of isolated nausea or vomiting persisting for more than 48 hours, acute digestive bleeding which is assumed to originate in the upper gastrointestinal tract (haematemesis or melaena), upper gastrointestinal endoscopy should be repeated when bleeding persists or when a first investigation including upper gastrointestinal endoscopy and colonoscopy has been inconclusive and for peptic ulcer. Peptic ulcer disease (PUD), gastroesophageal reflux disease (GERD) and cancers affect millions of people worldwide [2]. Upper Gastrointestinal (UGI) symptoms are among the commonest complaints for which patients seek medical attention, with the annual prevalence of dyspepsia approximating 25\% [1].

Uppergastrointestinal endoscopy is recommended if thereare symptoms of gastrooesophageal reflux combined with warning signs (weight loss, dysphagia, bleeding, anaemia), or if the patient is aged over 50 years, or if there is a recurrence on withdrawal of treatment or resistance to medical treatment. Endoscopy gives a better diagnostic yield over radiology particularly in the investigation of upper gastrointestinal bleeding, inflammatory conditions of the upper gastro-intestinal track like esophagitis, gastritis and duodenitis [3]. Upper gastrointestinal endoscopy for diagnostic purposes is recommended if portal hypertension is suspected, and particularly when cirrhosis is diagnosed, to look for any oesophageal or gastric varices. Biopsy during upper gastrointestinal endoscopy is indicated in the following situations such as esophageal and duodenal tumor and ulcer for the diagnosis of cancerous growth.

\section{Risks of an upper gastrointestinal endoscopy}

There are risks and complications with this procedure include some common risks and complications are, nausea and vomiting, Faintness or dizziness, especially when you start to move around, headache, pain, muscle aches and pains, allergy to medications given at time of the procedure. Some uncommon risks and complications include, about one person in every 1,000 will experience bleeding from the oesophagus (food pipe), 
stomach and duodenum where a lesion or polyp was removed. This is usually minor and can usually be stopped through the endoscope. Rarely, surgery is needed to stop bleeding. Heart and lung problems such as heart attack or vomit in the lungs causing pneumonia. Adverse events are inherent in performing the UGI endoscopic procedures. Because endoscopy assumes a more therapeutic role in the management of GI disorders, the potential for adverse events will likely increase.

\section{Acknowledgment}

I am deeply grateful to UGC for providing me UGC-BSR fellowship which helps me conducting my work smoothly and to the Dr. Sumit Rungta, Mr. Ram Pal, Prof. OMKAR for his valuable support and guidance.

\section{References}

1. Talley NJ, Vakil NB, Moayyedi P (2005) American gastroenterological association technical review on the evaluation of dyspepsia. Gastroenterology 129(5): 1756-1780.

2. Agbakwuru EA, Fatusi AO, Ndububa DA, Alatise OI, Arigbabu OA, et al. (2006) Pattern and validity of clinical diagnosis of upper gastrointestinal diseases in south-west Nigeria. Afr Health Sci 6(2): 98-103.

3. Aduful H, Naaeder S, Darko R, Baako B, Clegg-Lamptey J, et al. (2007) Upper gastrointestinal endoscopy at the Korle Bu Teaching Hospital, Accra, Ghana. Ghana Med J 41(1): 12-16.

\section{Your next submission with Juniper Publishers will reach you the below assets}

- Quality Editorial service

- Swift Peer Review

- Reprints availability

- E-prints Service

- Manuscript Podcast for convenient understanding

- Global attainment for your research

- Manuscript accessibility in different formats

( Pdf, E-pub, Full Text, Audio)

- Unceasing customer service

Track the below URL for one-step submission https://juniperpublishers.com/online-submission.php 